\title{
Deforestation, Agrarian Reform and Oil Development in Ecuador, 1964-1994*
}

\author{
Robert Wasserstrom ${ }^{1}$, Douglas Southgate ${ }^{2}$ \\ ${ }^{1}$ Terra Group, Hershey, Pennsylvania, USA; ${ }^{2}$ Department of Agricultural, Environmental and Development Economics, Ohio State \\ University, Columbus, USA. \\ Email: terragroup@iapc.net
}

Received October $13^{\text {th }}, 2012$; revised December $6^{\text {th }}$, 2012; accepted December $21^{\text {st }}, 2012$

\begin{abstract}
Recent biodiversity research in the Western Amazon has emphasized the linkages among road construction, deforestation and loss of indigenous lands. Many observers have concluded that hydrocarbon production inevitably means destruction of forests and expropriation of native territory. Yet evidence from the eastern lowlands of Ecuador (known as the Oriente) shows that oil can be developed without roads or harmful impacts. The Oriente also provides another contrasting case: in areas where no oil was discovered, the government often built roads to support its agricultural colonization efforts. In these areas, a great deal of deforestation and indigenous displacement occurred. Such evidence suggests that a different set of agrarian and environmental policies might permit oil activity without loss of rain forest or indigenous territory.
\end{abstract}

Keywords: Ecuador; Deforestation; Oil Development; Agrarian Reform; Colonization

\section{Introduction}

Recent biodiversity research in Western Amazonia has emphasized the linkages among road construction, deforestation of sensitive areas and loss of indigenous lands [1-3]. Much of this research focuses on petroleum development in the eastern lowlands of Ecuador (known as the Oriente), where "oil itself was located deep in primary forest and the extensive system of oil access roads... facilitated colonization and subsequent deforestation by small migrant farmers pursuing agriculture and cattle ranching” [4]. This formulation partly reflects the pioneering work of economist Sven Wunder, who reported that "the direct deforestation impacts of the oil industry from roads were negligible. The indirect impacts from oil roads to open up new areas for first timber extraction and then colonisation were more important, causing a spontaneous influx of agricultural squatters, who... gradually 'ate' their way into the forest [5]." Contemporary events in Ecuador seem to bear him out. Between 1964 and 1994, nearly one-fifth of the country's eastern forests disappeared (Table 1), while indigenous communities retained only a small fraction of their original lands. Despite Wunder's findings about colonization, however, most researchers continue to blame oil production as the

\footnotetext{
*The authors are deeply indebted to an anonymous reviewer, who significantly improved our article. They would also like to thank Dr. James Ellis for providing his satellite maps of the Ecuadorian rainforest.
}

Table 1. Deforestation in the Oriente, 1965-2000 ${ }^{1}$.

\begin{tabular}{cccc}
\hline \multirow{2}{*}{ Province } & \multirow{2}{*}{ Hectares $(\mathrm{mm})$} & \multicolumn{2}{c}{ Deforestation } \\
\cline { 3 - 4 } & & Hectares & $\%$ \\
\hline Sucumbíos & 1.79 & 267,000 & 14.9 \\
Orellana & 2.17 & 404,700 & 18.7 \\
Napo & 1.25 & 421,300 & 33.8 \\
Pastaza & 2.91 & 222,800 & 7.7 \\
Morona Santiago & 2.39 & 601,200 & 25.2 \\
Zamora Chinchipe & 1.05 & 236,900 & 22.4 \\
Total, Oriente & 11.6 & $2,153,900$ & 18.6 \\
\hline
\end{tabular}

primary cause of harm.

Yet for Ecuador, this account overlooks a major driving force of deforestation: the government's agricultural development and colonization policies. Settlement in the Ecuadorian Amazon remained a central focus of government policy throughout the late 19th and 20th Centuries. Through shifting political currents and economic fortunes, virtually every administration took steps to occupy and subdue the rain forest. In 1875, the government declared its Amazonian territories to be "vacant land" and open for colonization; they remained open until the government formally ended colonization in 1994. In 1963,

${ }^{1}$ Adapted from Reference [6]. 
authorities in Quito identified target areas for agricultural settlement in the Oriente and designed a "master plan" for colonization. The following year, Ecuador's new military rulers began a massive transfer of native lands to migrant homesteaders, who were recruited from the highlands and Pacific Coast.

In contrast, oil production did not start until 1972, the same year a highway from Quito to Lago Agrio (the production center) was completed (Figure 1). Without question, settlers used this highway to enter the Oriente. But even where oil was absent, the government undertook public works needed for colonization and demanded that oil companies build roads and bridges-whether or not such infrastructure was needed for petroleum development.

In this paper, we will reevaluate the relative impact of oil development and colonization policy on Ecuador's eastern rain forest. The Oriente offers a unique opportunity to analyze development policy, because it can be divided into four distinct zones that allow for detailed comparison:
1) The northern region, with extensive road construction, oil production and colonization.

2) Pastaza Province, where oil development took place without roads or colonization.

3) Morona Santiago Province, where roads were built to encourage settlement but oil was never found.

4) The remote eastern frontier without oil development, roads or settlers.

Comparing and contrasting such cases lead to broader conclusions about development policy. Many investigators now argue that oil and gas production are inherently destructive and cause deforestation, loss of indigenous lands and other damage [7-12]. But our evidence shows that this need not be the case. Far more significant, we argue, was the Ecuadorian government's early intention to expand agricultural colonization into Amazonia. Oil exploration in the northern Oriente was used opportunistically to build the infrastructure for settlement and for crop and livestock production. This conclusion suggests that a different set of policies might permit oil or mining activity without loss of rain forest or native lands.

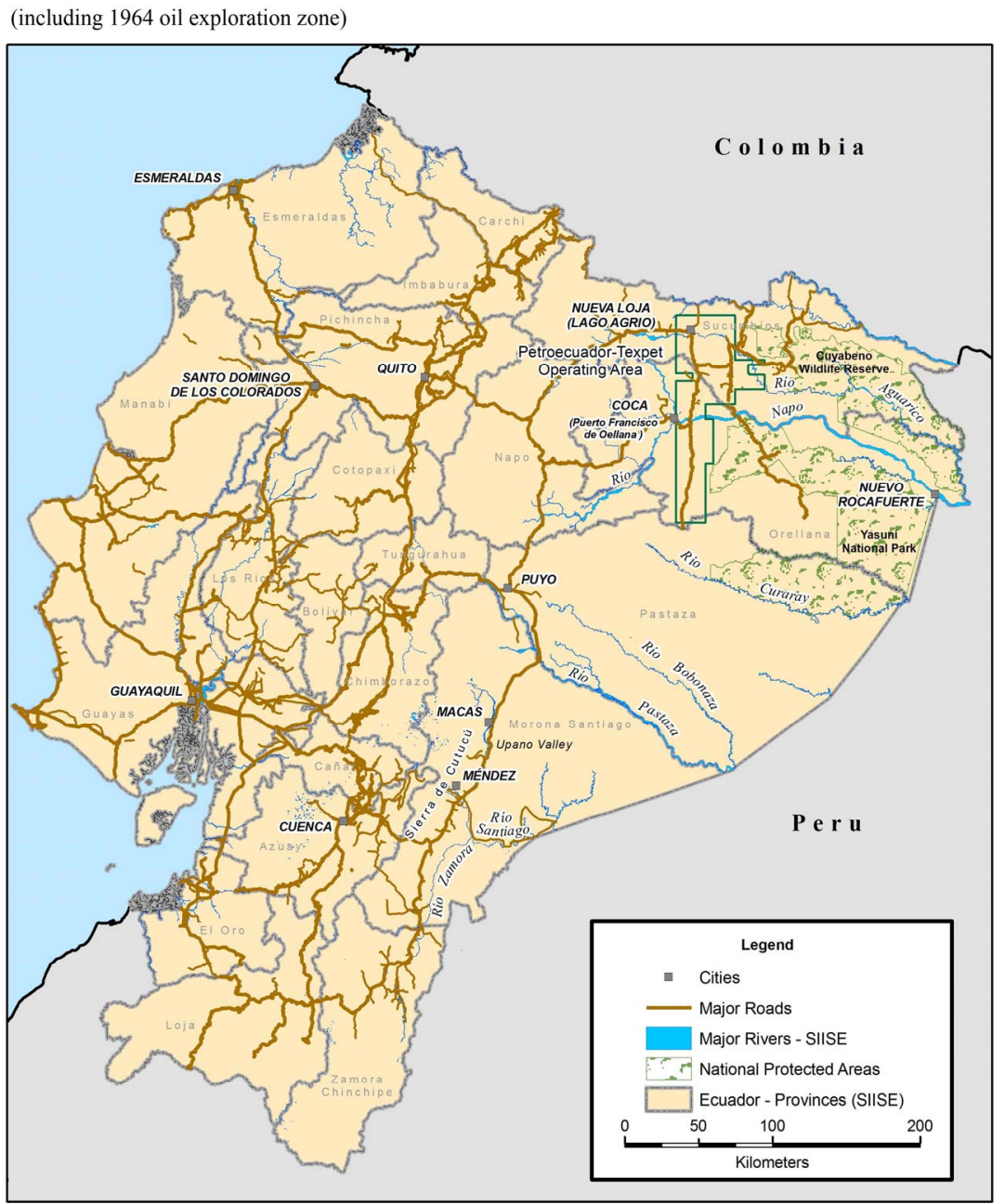

Figure 1. Ecuador and its eastern rainforest. 


\section{Development Policy in Ecuador}

When oil was discovered near Lago Agrio in April, 1967, the Ecuadorian government looked forward to investing heavily in national development [13]. Ecuador had one of the poorest, most rural and fastest growing populations in the Western Hemisphere. Its gross national income (GNI) per capita was little more than half the average for Latin America and the Caribbean as a whole; only Haitians had an average income that was significantly lower. Ecuadorians born in 1967 could expect to live 57 years, less than the hemisphere's average age of 59 years. Meanwhile, at 3\%, Ecuador's annual population growth exceeded the rate for the region as a whole, which was $2.7 \%$ [14].

Thanks to oil money, GNI per capita in Ecuador grew faster during the 1970s than in any other nation in the Western Hemisphere. By the end of the decade, oil exports brought in $\$ 1.035$ billion and represented more than half of all government revenues [15]. Nearly four-fifths of this revenue was used to expand public sector employment and increase salaries [16]. In turn, improvement in living conditions for middle class families drove up the demand for food, especially livestock products [17]. Increasing demand and accelerated currency appreciation would most likely have resulted in a flood of imported beef, pork and chicken. To prevent this, the government imposed tariffs that protected domestic suppliers. Ranchers and other livestock producers became major beneficiaries of the growth in domestic markets, as were suppliers of non-tradable services [18].

Government policies stimulated expansion of the livestock sector in other ways. Enriched by oil revenue, official agencies offered subsidized credit that favored specific economic sectors [19]. During the 1970s, for example, nearly every loan from the National Development Bank (BNF), a public credit agency, favored livestock producers ${ }^{2}$. Moreover, cheap credit was directed overwhelmingly toward larger operators: only $10 \%$ of the country's 700,000 farmers received BNF loans [22]. Especially in the highlands, large landowners used borrowed money to mechanize and expand their operations. As economist Carlos Larrea notes, mechanization often reduced farm-related employment, which declined from 873,000 jobs in 1974 to 773,000 in 1982 [23]. Many laidoff workers moved to urban slums or returned to cultivating small highland plots. Others joined the ranks of agricultural colonists settling in the Oriente. At the same time, national production of rice, potatoes and other basic food crops dropped by 30\% [21]. And finally, through

\footnotetext{
${ }^{2}$ In 1979, the World Bank found that $90 \%$ of these loans supported cattle production [20]. Another government lender, the Banco Cooperativo, supported only landowners who owned more than 100 hectares. By 1984, $60 \%$ of all agricultural credit was channeled toward livestock [21].
}

the 1970s and 1980s, the government offered subsidies and tax holidays to large palm oil growers and cattle ranchers if they cleared new land in peripheral places like the Amazon basin [24].

Other public subsidies directly accelerated the geographic expansion of agriculture into lowland forests. During the 1970s, gasoline in Ecuador rarely cost more than \$0.10/gallon, far lower than international prices. Even during the 1980s, domestic prices rose to only $\$ 0.30 /$ gallon [25]. Although low energy prices may have benefited everyone, they were especially advantageous for farmers in remote settings like the Oriente. Meanwhile, improvements in agricultural technology received little support, which was reflected in low crop and livestock yields. By the late 1980s, rice yields in Ecuador (2.3 metric tons per hectare) had sunk to less than half of yields in Colombia (4.7 tons) and Peru (4.8 tons)-despite the fact that farming conditions for rice are ideal in the Guayas River basin [26]. Ecuador's per-hectare production of grain and tubers was lower in 1998 than yields in Colombia, Peru and Venezuela [27] $]^{3}$. Simultaneously, the rising demand for food led to a sharp expansion in agricultural land use. For two decades starting in the mid-1970s, two-thirds of the increase in Ecuador's crop and livestock output resulted from the spread of areas under cultivation; rising yields accounted for only onethird of that increase [29].

\section{Land Reform}

\subsection{The First Land Reform, 1964-1972}

In 1964, Ecuador's new military rulers decided to address one of the country's most serious economic and political problems: agrarian reform. Since the country's first agricultural census in 1954, many Ecuadorian officials recognized that "agrarian reform was necessary if industrialization was to be achieved" [30]. At the time, $0.4 \%$ of all proprietors occupied $45 \%$ of total farmland, while $90 \%$ of farms (owned by half of the country's population) were too small to support a single family [31, 32]. Previous governments had made timorous efforts to address these problems. In 1957, President Camilo Ponce Enríquez established the Instituto Nacional de Colonización (INC, National Colonization Institute), which later became the Instituto Ecuatoriano de Reforma Agraria y Colonización (IERAC, the Ecuadorian Institute for Agrarian Reform and Resettlement). But support for land redistribution was always limited. Among other things, landowners objected to the abolition of indebted labor (known as precarismo or huasipungo) on their estates

\footnotetext{
${ }^{3}$ According to Pichón, "Yields of almost all crops in Ecuador are lower than in neighboring Colombia and Peru, and in some cases are markedly lower..." He also writes that "in wheat, beans, and soybeans, yields have actually declined since the early 1990s [28].”
} 
and opposed any limitation on farm size. As Redclift writes, "Five years after the 1964 Law was introduced it was calculated that, at the current rate at which land was being handed over to former huisipungueros, it would be one hundred and seventy years before all the precaristas in Ecuador were in possession of land [33].”

Although land reform largely failed in the highlands, government officials achieved greater success in resettling impoverished families on "vacant lands" along the northern coast and in the southern Amazon. In 1963, military rulers asked the Junta Nacional de Planificación y Coordinación Económica (National Planning Board, known as JNPC) to prepare an inventory of potential "colonization" areas, along with a master plan for settling them (Figure 2) [34].

But without roads, most of the Amazon remained out of reach ${ }^{4}$. Until the mid-1960s, only one under-populated part of Ecuador could be reached by highway: the coastal rain forest between Santo Domingo de los Colorados and
Esmeraldas. Then beginning in 1965, another region opened to colonization: the Andean foothills of Morona Santiago province, east of Cuenca. With support from the Inter-American Development Bank, regional authorities in Cuenca built a road network that eventually extended deep into "unoccupied" areas that lay within traditional Shuar and Achuar territory [20,38]. By 1973, IERAC had issued provisional title for 212,000 hectares to 4000 beneficiaries [20].

\subsection{The Second Land Reform, 1973-1979}

In 1966, Ecuador's military authorities relinquished power to a civilian administration that governed until 1972, when the armed forces again took control (until 1979). By this time, highland hacendados had sold off significant holdings, but they still owned a third of the country's total (and best) agricultural land. In contrast, $70 \%$ of rural households tried to survive on less than $8 \%$ of all farmland. For the most part, food production stagnated.

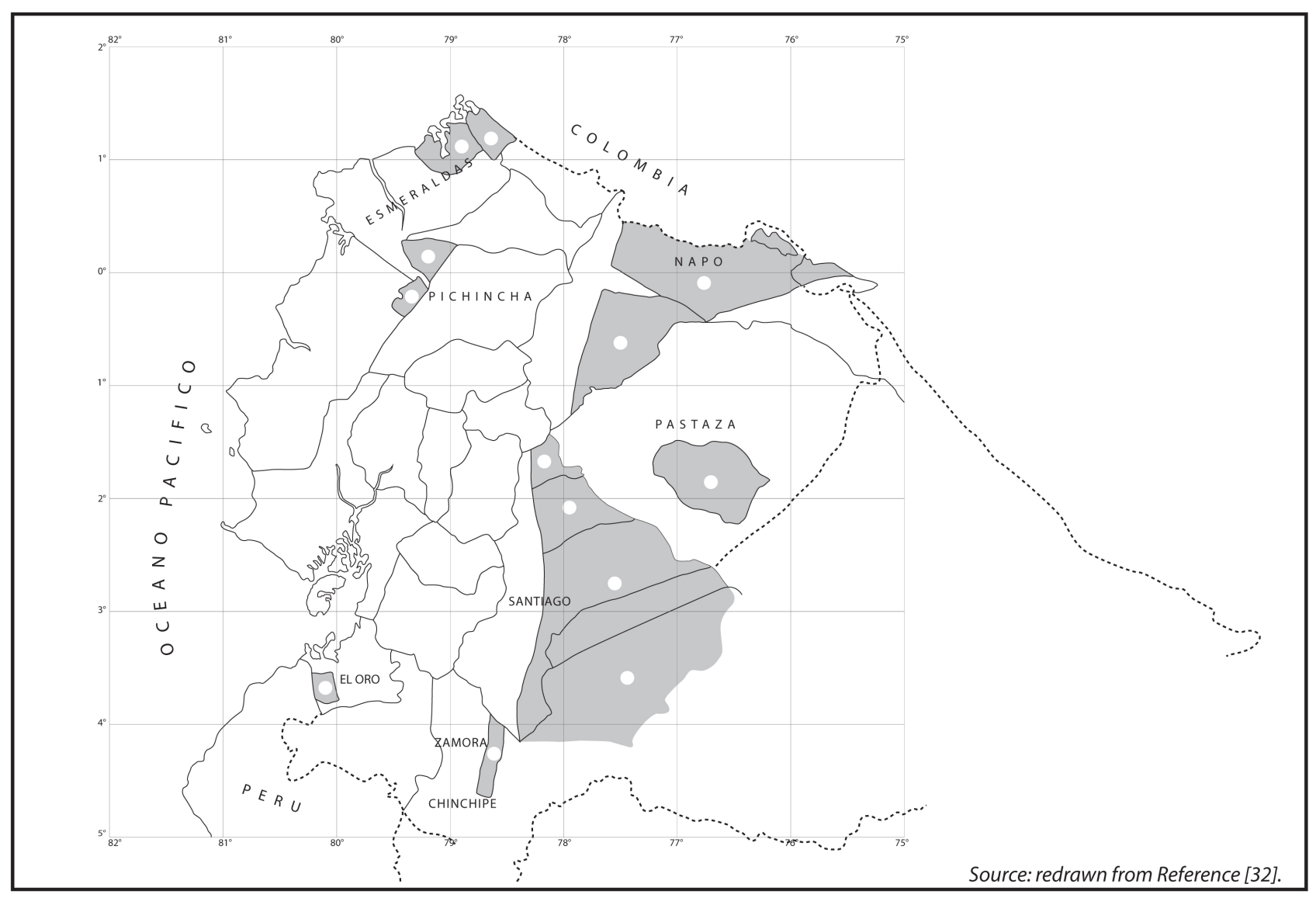

Figure 2. Designated colonization zones, 1963.

\footnotetext{
${ }^{4}$ Bromley provides an early discussion of this issue [35]. In a few instances, large haciendas spread along the most accessible headwaters of major rivers: the Napo, Pastaza and Curaray. According to Uquillas, however, early settlers focused primarily on land speculation or logging [36]. Brown et al. point out that early migrations closely followed commodity cycles: "With respect to the Oriente, increases in world demand for rubber, gold, quinine and petroleum motivated successive waves of settlement, and decreases in demand dampened or reversed those waves, leading to a boom and bust economy [37].”
} 
Soon after taking power, military rulers created a new state oil company, the Corporación Estatal Petrolero Ecuatoriana (CEPE, later renamed Petroecuador) and joined OPEC. They rewrote the National Hydrocarbons Law to underscore governmental ownership of the country's petroleum reserves, along with its exclusive right to explore and develop them. New contracts were signed with Texpet (the Texaco-Gulf Consortium that discovered oil in 1967), thereby making CEPE an equity partner. Henceforth, foreign companies were also "required to pay surface and entry rights, royalties, tax contributions for education, transportation fees for pipeline usage, and compensatory public works in the region contracted [39]."

The emphasis on public works is significant. Since the 1920s, when it adopted its second Ley del Oriente, the Ecuadorian government had looked to oil companies for "dual purpose" infrastructure [40]. In 1947, for example, Shell built a road from Ambato (in the central highlands) to Puyo, opening part of the central Amazon to settlement. It also built an airport at Shell-Mera and a network of local penetration roads. As oil exploration proceeded, these roads were extended and eventually connected to the highway from Morona Santiago, farther to the south. In September, 1971, at the government's direction, Texpet completed a highway from Quito to Lago Agrio (paved in 1972). By contract, Texpet was also required to build other infrastructure-including highways, bridges and the Lago Agrio airport-worth $\$ 55.5$ million (including \$20 million of penetration roads unrelated to oil development) [41]. For the first time, Ecuadorian officials could now envision fulfilling their aspiration of colonizing the northern Amazon (Figure 3).

Like its predecessor, the military government that came to power in 1972 viewed land reform as an essential precondition for economic progress. But reform advocates quickly ran into opposition from landowners and more conservative military officers. As in 1964, proposed ceilings on landholdings became the stumbling block. As a compromise, the 1973 Agrarian Reform Law set no limits on farm size, as long as these holdings fulfilled a legitimate "social function": efficient agricultural production [42].

But what was to be done with the 1.85 million highland peasants who had received nothing at all under land reform? Most of these families lived on less than one hectare and survived as seasonal migrants on coastal plantations or in the cities. "By 1973," Redclift notes, "it was abundantly clear that no redistributive land reform was likely, at least in the short term, and that the main efforts of the military would be expended in efforts to "modernize' agricultural production on the latifundia [43].” As a result, Zevallos adds, "colonization became an alternative

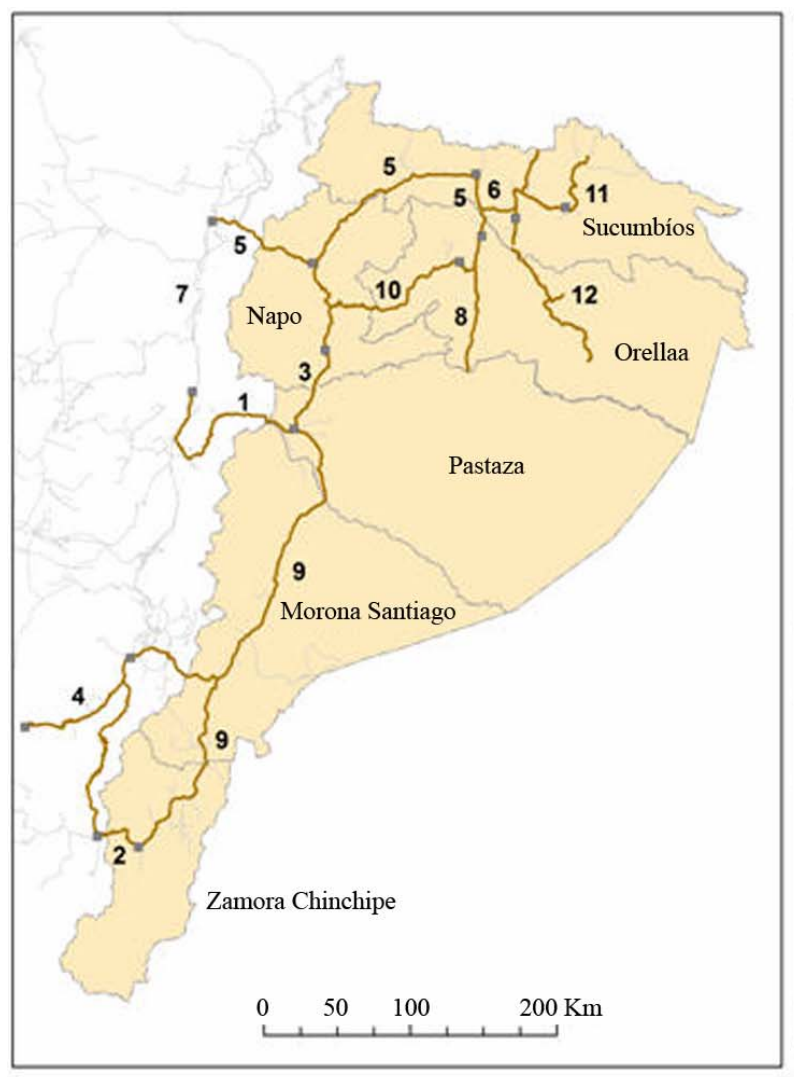

\begin{tabular}{|c|c|c|c|}
\hline & Route & Built by & Completed in \\
\hline 1 & Ambato to Puyo & Shell & 1947 \\
\hline 2 & Loja to Zamora & $\begin{array}{l}\text { Government of } \\
\text { Ecuador }\end{array}$ & 1960 \\
\hline 3 & Tena to Puyo & Shell & 1950 \\
\hline 4 & Cuenca to Limon & CREA* & 1970 \\
\hline 5 & $\begin{array}{l}\text { Quito to Lago Agrio } \\
\text { and Coca }\end{array}$ & $\begin{array}{l}\text { Petroecuador- } \\
\text { Texaco }\end{array}$ & 1971 \\
\hline 6 & $\begin{array}{l}\text { Sacha to } \\
\text { Shushufindi }\end{array}$ & $\begin{array}{l}\text { Petroecuador- } \\
\text { Texaco }\end{array}$ & pre-1973 \\
\hline 7 & Puyo to Quito & CREA* & pre-1976 \\
\hline 8 & Sacha to Cononaco & $\begin{array}{l}\text { Petroecuador- } \\
\text { Texaco }\end{array}$ & pre-1984 \\
\hline 9 & $\begin{array}{l}\text { Zamora to Puyo, } \\
\text { Tena to Baeza }\end{array}$ & CREA* & $1982-1987$ \\
\hline 10 & Coca to Tena & $\begin{array}{l}\text { Government of } \\
\text { Ecuador }\end{array}$ & 1988 \\
\hline 11 & $\begin{array}{l}\text { Tarapoa to the Río } \\
\text { San Miguel } \\
\text { (throuth the } \\
\text { Cuyabeno Reserve) }\end{array}$ & $\begin{array}{l}\text { Government of } \\
\text { Ecuador }\end{array}$ & 1980's \\
\hline 12 & Block 16 & Maxus & 1994 \\
\hline
\end{tabular}

Figure 3. Highway construction in the Oriente, 1947-1994. 
to agrarian reform [44].” In 1972, as the Quito-Lago Agrio road was nearing completion, the government declared that oil development would enable the northeast to become a target "area for migration and expansion.” It offered 50-hectare parcels of land in the Oriente and required settlers to clear half of their holdings within five years to show "effective use." Colonization, not land reform, became the dominant force in reshaping Ecuador's countryside (Figure 4).

\section{Colonization and Resettlement: Four Cases}

Were deforestation and the loss of native land an unavoidable outcome of petroleum development, as many scholars have argued, or were these problems largely a consequence of misguided economic policies ${ }^{5}$ ? Beginning in 1964, migrants from the highlands and Pacific Coast poured into the eastern forests and claimed "vacant"

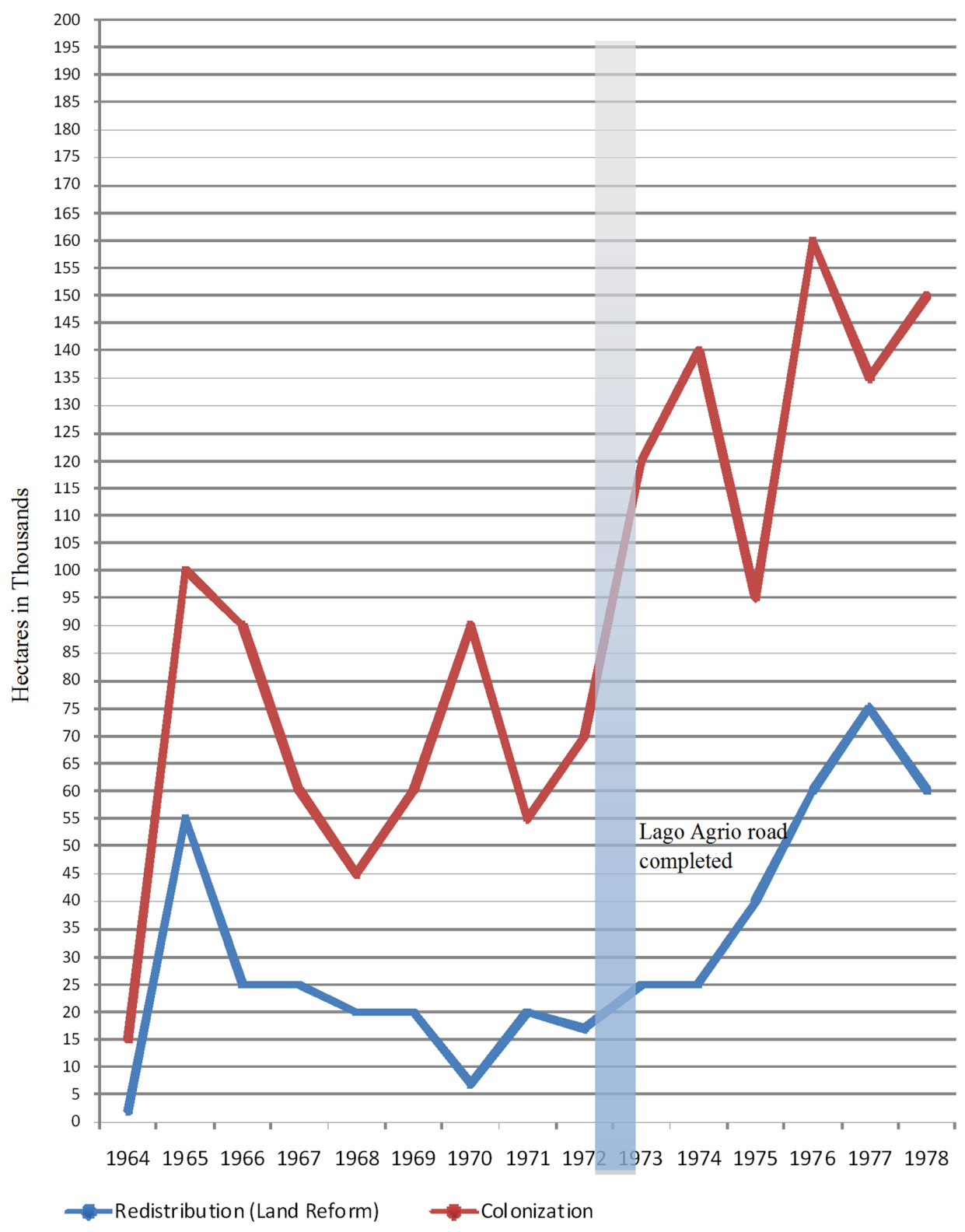

Adapted from Reference [45].

Figure 4. Land reform and colonization, 1964-1978.

\footnotetext{
${ }^{5}$ In our analysis of deforestation, we have used satellite imagery from 2000 because this is the first year that it was available after the frontier was closed. Data were adapted from Reference [6] and from the Centro de Levantamientos Integrados de Recursos Naturales por Sensores Remotos (CLIRSEN), available online at http://www.clirsen.gob.ec/clirsen/index.php?option=com_frontpage\&Itemid=1. We are grateful to Dr. James Ellis for sharing his analysis with us.
} 
land under the country's new colonization laws (Table 2). Analysis of satellite imagery and historical data allow us to compare how such events unfolded in four cases.

\subsection{The Northern Oriente (Oil Development, Roads and Colonization)}

Until 1972, a few migrants entered this area-mostly settlers pushing north along the Puyo-Tena road. After the highway from Quito to Lago Agrio was completed, however, colonos poured in from all parts of Ecuador, especially drought-stricken Loja Province in the southern Andes. Colonization brought significant consequences for the region's indigenous population. Virtually all of the "vacant" land identified by government officials in their 1963 settlement plan was located within traditional territories used by the Cofán, Siona-Secoya and Huaorani people. According to Uquillas, "The fact that large portions of land are considered 'fallow' or have no owner other than the state (frequently ignoring prior rights of possession of indigenous inhabitants) has incited the unrestrained taking of lands by immigrants to the petroleum zone. In areas of highway construction (or projected construction), colonists take possession of the land and commence deforestation [48]."

Only the first homesteaders who lived along new roads enjoyed relatively easy access to outside markets. They planted crops such as coffee, maize or plantains on homesteads that measured 200 - 250 meters wide by $2 \mathrm{~km}$ deep. Later arrivals settled farther from roads, with little prospect of raising anything but cattle. By 1978, according to Hiraoka and Yamamoto, "colonists were clearing parcels... eight or ten kilometers distant from the trunk routes [49]." Many of these colonists knew that their farms were commercially unviable, but were speculating that access roads would be built later.

In September, 1980, government officials convened an inter-ministerial committee to resolve the conflict between colonos and native communities. Representing traditional "developmentalist" agencies, most committee members argued that 50 hectares per family were generous for semi-nomadic native farmers and that larger land grants would be wasted. Independent experts conducted field studies among the Cofán, Siona-Secoya and Huaorani, and tried to explain why native economies required more

Table 2. Population of the Oriente, 1962-1992 ${ }^{6}$.

\begin{tabular}{cc}
\hline Year & Population \\
\hline 1962 & 25,582 \\
1974 & 55,142 \\
1982 & 115,110 \\
1992 & 371,110 \\
\hline
\end{tabular}

${ }^{6}$ Adapted from References [46,47]. extensive lands. Ultimately, however, the government approved only modest grants to native communities [36]. By 1990, the Siona-Secoya had obtained title to just over 40,000 hectares; almost 680,000 hectares of Huaorani land were legally protected from invasion; eventually, the Cofán received 34,000 hectares (subsequently increased to 69,000 hectares). For the Cofán and SionaSecoya, such grants ensured their bare survival, but excluded most of their original territories (totaling nearly 3 million hectares).

Homesteading was not successful for everyone. Many farmers failed, because they missed their annual land payments, lacked credit, lost cattle, or couldn't grow enough food. IERAC procedures were complicated and often required fees, bribes and expensive trips to Quito or Lago Agrio. Land could not be sold legally without permanent title. If hardship struck, many colonos abandoned remote farms for a fraction of their potential market value, allowing larger landowners to expand their holdings. Ultimately, wrote Hiraoka and Yamamoto, this process would defeat the purpose of agricultural settlement: "social and economic roles envisaged for the Oriente-provision of better financial opportunities and the poor and relief of demographic pressures from the Andean core regions - will not be realizable [50].” To make matters worse, government officials also allocated far larger parcels in the northern Oriente to commercial agriculture. By 1978, they had already given grants of 10,000 hectares and 60,000 hectares to corporate operators for oil palm and livestock production. Subsequently, 9,500 hectares of traditional Siona-Secoya hunting territory were awarded to Palmeras del Ecuador for an African oil palm plantation. A few years later semi-clandestine logging spread into the Cuyabeno Wildlife Reserve along roads built by the state oil company, Petroecuador (Figure 5) [51,52].

\subsection{Pastaza Province (Oil Development without Roads)}

Pastaza Province shares a long border with Peru, guarded by remote army garrisons. Until 1947, its capital, Puyo, housed a small Catholic mission and neighboring village. Completion of roads to Macas and Ambato transformed the settlement into a commercial and administrative center. By 1966, it was surrounded by large ranches and sugar plantations, as landowners took advantage of the 1964 Agrarian Law to annex lowland Quichua territory $[53,54]$.

Traditionally, lowland Quichua people were divided into two groups: Quijos (Napo Runa) and Canelos (Puyo Runa). By the mid-19th Century, many Runa-at least those who lived closest to Puyo and Tena-had become indebted peons on lowland haciendas (also called fundos 


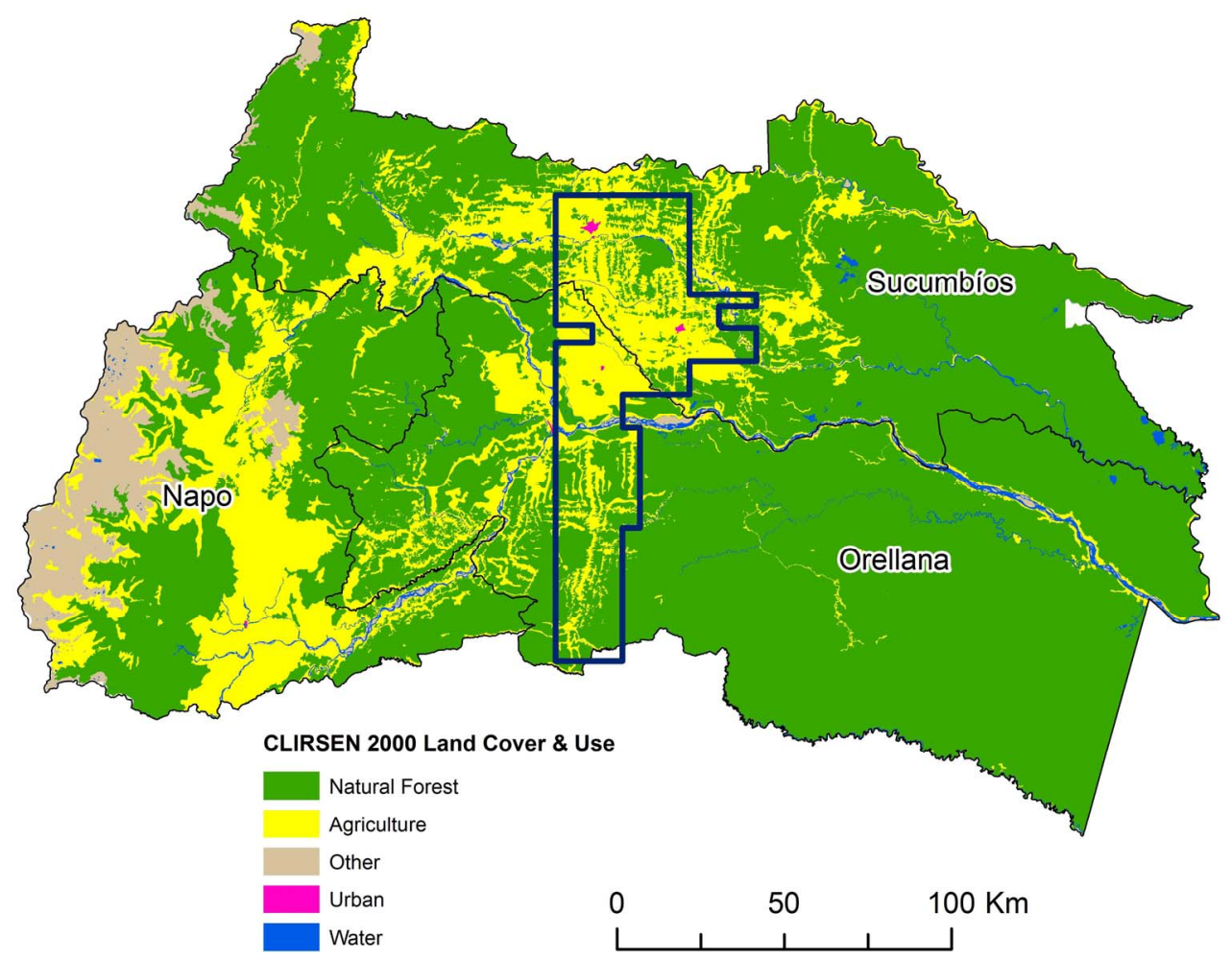

Figure 5. Land use in Sucumbíos, Orellana and Napo Provinces, 2000.

in Ecuador). During the mid-20th Century, they often found opportunities to work elsewhere or find temporary employment with petroleum companies. Wages in the oil fields were far superior to peonage on lowland fundos. At first, local men worked for Shell, which explored for oil in the Oriente between 1937 and 1950. Later, they signed on with Texaco or other companies. Although a few families moved to Lago Agrio, an important Texaco base, more often the men took temporary jobs there (the normal labor contract lasted 90 days), while their wives and children remained behind on the chacra (farm).

This situation changed in the late 1950s and early 1960s, as colonos invaded Runa territory along the PuyoTena road. In response, the Runa there abandoned their traditional subsistence economy and subdivided communal lands into individual parcels, which they cleared for pasture [55]. As cattle ranches, their lands could be titled and protected. They understood the 1964 Agrarian Reform Law and the laws that followed — many of them had moved from Tena to escape colonization - and they took preemptive action. Farther south, around Puyo, Quichua communities also adopted livestock production in order to hold onto their land [56].

In 1988, ARCO signed a contract with Petroecuador to explore Shell's old fields in Pastaza. A few years later, it discovered significant reserves in Villano, a cluster of several small villages located in undistributed rain forest about $100 \mathrm{~km}$ east of Puyo [57]. In 1998, the company completed work on production facilities and a secondary pipeline connecting Villano with SOTE, Ecuador's main pipeline system. To minimize environmental impacts, ARCO built its facilities using an "off-shore" strategy that required no roads. During construction, all equipment, supplies and workers were transported by helicopter. A small "flow line" was laid above ground to avoid damaging tree roots and leave the forest canopy intact. Oil was stored at a central processing facility outside the jungle, rather than in large tanks at Villano [58]. Where the flow line emerged from undisturbed forest, it was deliberately routed across an impassible escarpment to block easy entrance for potential settlers.

Opposition to the off-shore model came from two quarters: local communities and Petroecuador. Community members lobbied intensively for an access road allowing them to market their cattle and other products in Puyo. When ARCO refused, they held three company employees hostage for ten days in 1998 until provincial leaders negotiated their release. Petroecuador also wanted a road: in its view, road construction remained a key to economic development in the region and part of its public responsibilities. After lengthy discussions, ARCO agreed to build secondary roads elsewhere along the Puyo-Baeza Highway in areas where deforestation had already occurred. So far, it seems, the offshore model has worked: in 2001, satellite imagery showed that only $1.6 \%$ of the Villano area had been deforested (Figure 6). 


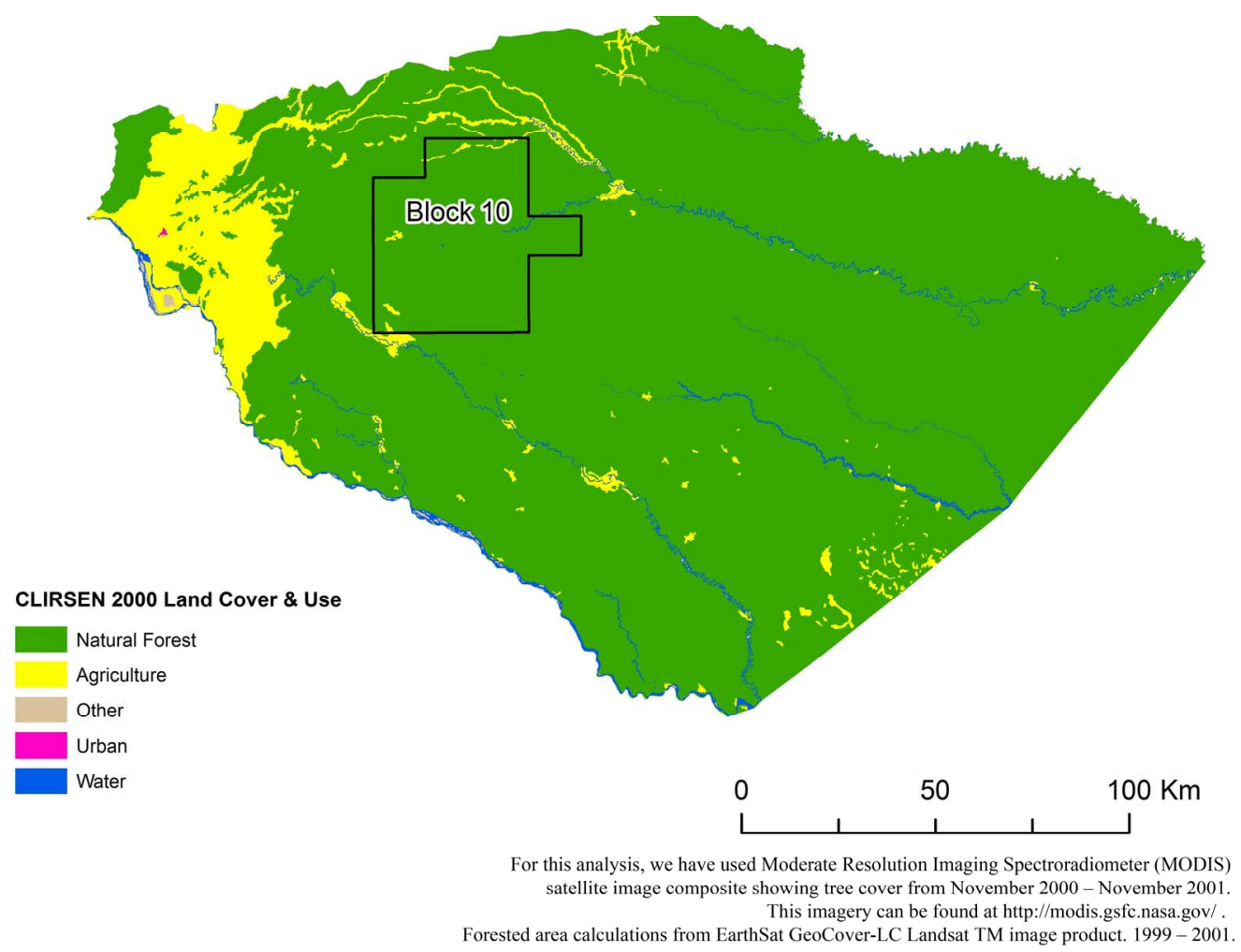

Figure 6. Land use in Pastaza Province, 2000.

\subsection{Morona Santiago (Roads and Colonization without Oil)}

In 1893, Salesian missionaries from Italy arrived in Morona Santiago to "civilize and indoctrinate" Shuar and Achuar communities (collectively known as "Jívaro") numbering as many as 10,000 inhabitants [59]. Until the mid-1960s, these groups lived in extended households headed by closely related men. Large distances separated family groups. Periodically, Jívaro war parties raided other Shuar and Achuar settlements. During these raids, several families might come together in one large house until the danger had passed [60]. Between 1940 and 1960, according to Taylor, such raids became so frequent that one out of every two Achuar men was killed in warfare [61]. Survivors described those years as a time when "we were ending."

Around 1900, one small group of 400 mestizo immigrants settled in the Upano Valley, located within Shuar territory along the Andean foothills. Unable to transport their crops to the highlands, they lived in near total isolation. Other settlers began to arrive in the 1930s, when Salesian missionaries built a trail through the mountains to their mission in Méndez, located in the lowlands 100 $\mathrm{km}$ east of Cuenca.

Conflict quickly arose between colonists and Shuar communities in the Upano region. "As the colonists became more numerous during the 1930s and 1940s," write Rudel and Horowitz [62], "their demands for land began to disturb the Shuar. The colonists converted as much forest to pasture as possible; only the steepest slopes remained forested... In contrast the Shuar practiced shifting cultivation which left the basic structure of the forest intact." By the 1950s, Salesian missionaries became alarmed at the growing influx of settlers and occupation of native territories. Early efforts to obtain land titles for Shuar families went awry when native "landowners" sold their parcels to outsiders. The Salesians then hit upon the idea of forming centros (centers) under the 1937 Rural Communes Law: "The Shuar in an area would form a centro, an organization of villagers, and it would receive title to a large tract of land around the village. Each household in the village would receive a tract of land in the centro. Household heads could sell their land to other members of the centro, and they could pass it on to their sons and daughters, so individuals considered themselves to be the 'owners' of their tract of land. They could not sell their land to outsiders [62]."

In 1964, Shuar leaders formed the Federación de Centros Shuar (FICSH, the Federation of Shuar Communities), which began an aggressive campaign to defend Shuar territory. Settlers reacted forcefully. In 1977, they persuaded the military government to create a "national reserve” for colonists east of the Cordillera de Cutucú. Between 1976 and 1988, IERAC slowed its processing of Shuar and Achuar land claims, thus giving migrants time 
to occupy new land. Still, 83\% of eastern Morona Santiago remained in native hands. By the late 1980s, the settlement frontier stabilized, because no new roads were built farther east. Nonetheless, migrants and Indians alike cut down the forest. Virtually all colonos aspired to raise cattle. And like the Runa in Pastaza Province, Shuar (and eventually Achuar) communities adopted similar strategies. Beginning in the early 1960s, Salesian missionaries persuaded indigenous leaders that cattle production was their best defense against encroachment and lent livestock to native communities.

"In the early 1970s," Rudel and Horowtiz write, "the federation, using funds donated by European development agencies, began making loans to Shuar centros for the development of their cattle herds [62].” Within a few years, traditional communities - and relatively intact forests-remained only in eastern Morona Santiago, far from existing roads (Figure 7). The 1973 Agrarian Reform Law cemented this pattern in place.

\subsection{The Remote Frontier (No Roads, Oil or Colonization)}

Beyond these frontiers, Ecuador's eastern rain forest has remained largely undisturbed. Sporadic settlement has not brought significant change. In the late 19th and early 20th Centuries, Ecuadorian and Peruvian landowners created a string of haciendas down the Napo River as far as Iquitos. Many of the Quichua-speaking communities that subsequently received land there under the 1973 Agrarian Reform Law included the descendents of laborers on these haciendas.

The economic decline of Iquitos and the 1941 border war with Peru put an end to settlement along the lower Napo. Periodically, Petroecuador has tried to interest foreign oil companies in developing heavy oil reserves near Nuevo Rocafuerte, but so far with little success. Similarly, eastern Pastaza and Morona Santiago Provinces remain too isolated for settlement. In 1984, Petroecuador explored for oil along the Peruvian border, but abandoned these efforts shortly thereafter [63]. Ominously, Petroecuador has also drilled several exploration wells in the Cuyabeno Wildlife Reserve and has begun to build production facilities in a protected forest adjacent to the Reserve. For now, however, these areas appear to be safe from large-scale deforestation, since most rivers flow eastward from the Andean foothills into the Amazonian interior, making it difficult to market illegally harvest timber (Figure 8).

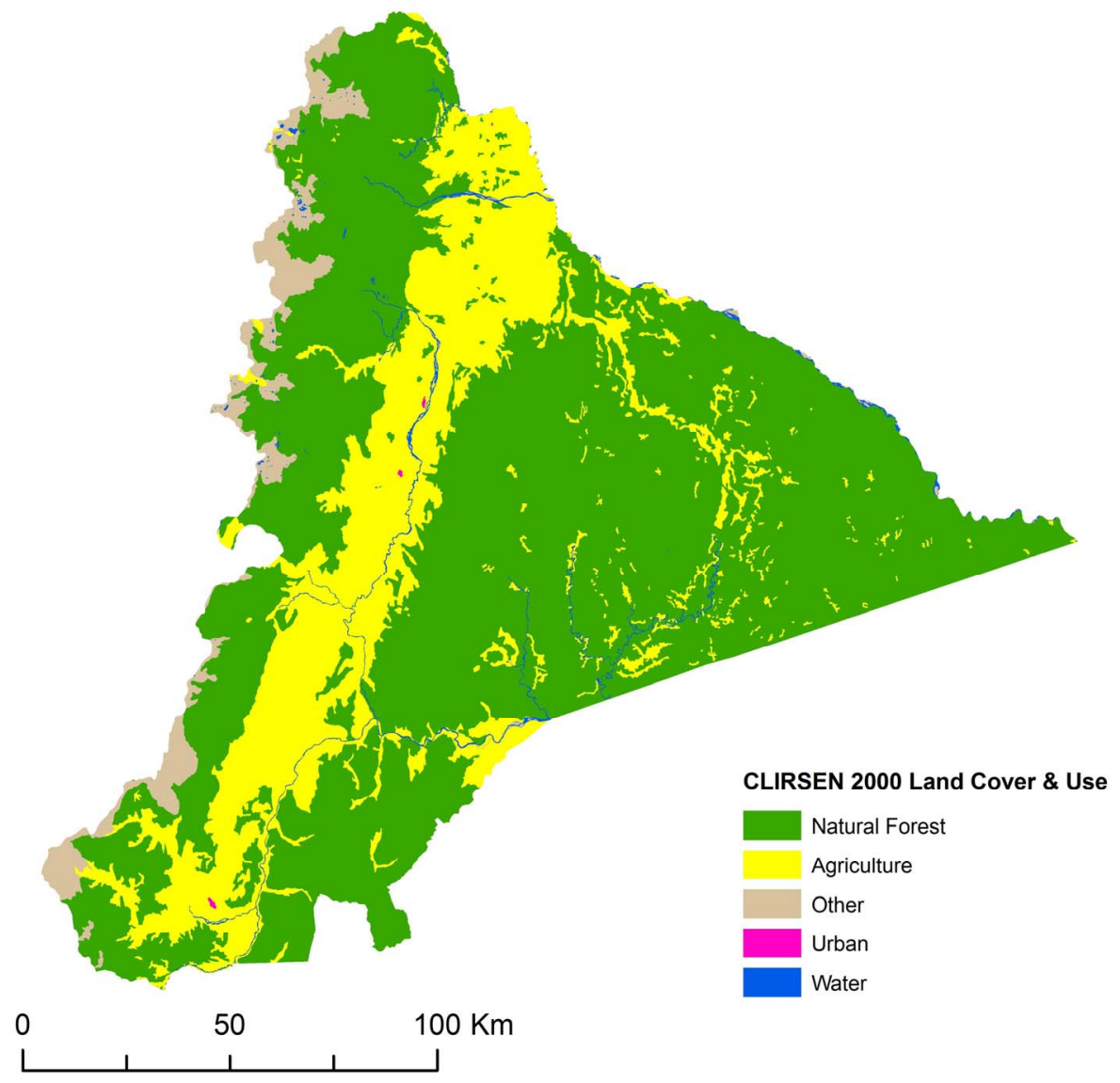

Figure 7. Land use in Morona Santiago Province, 2000. 


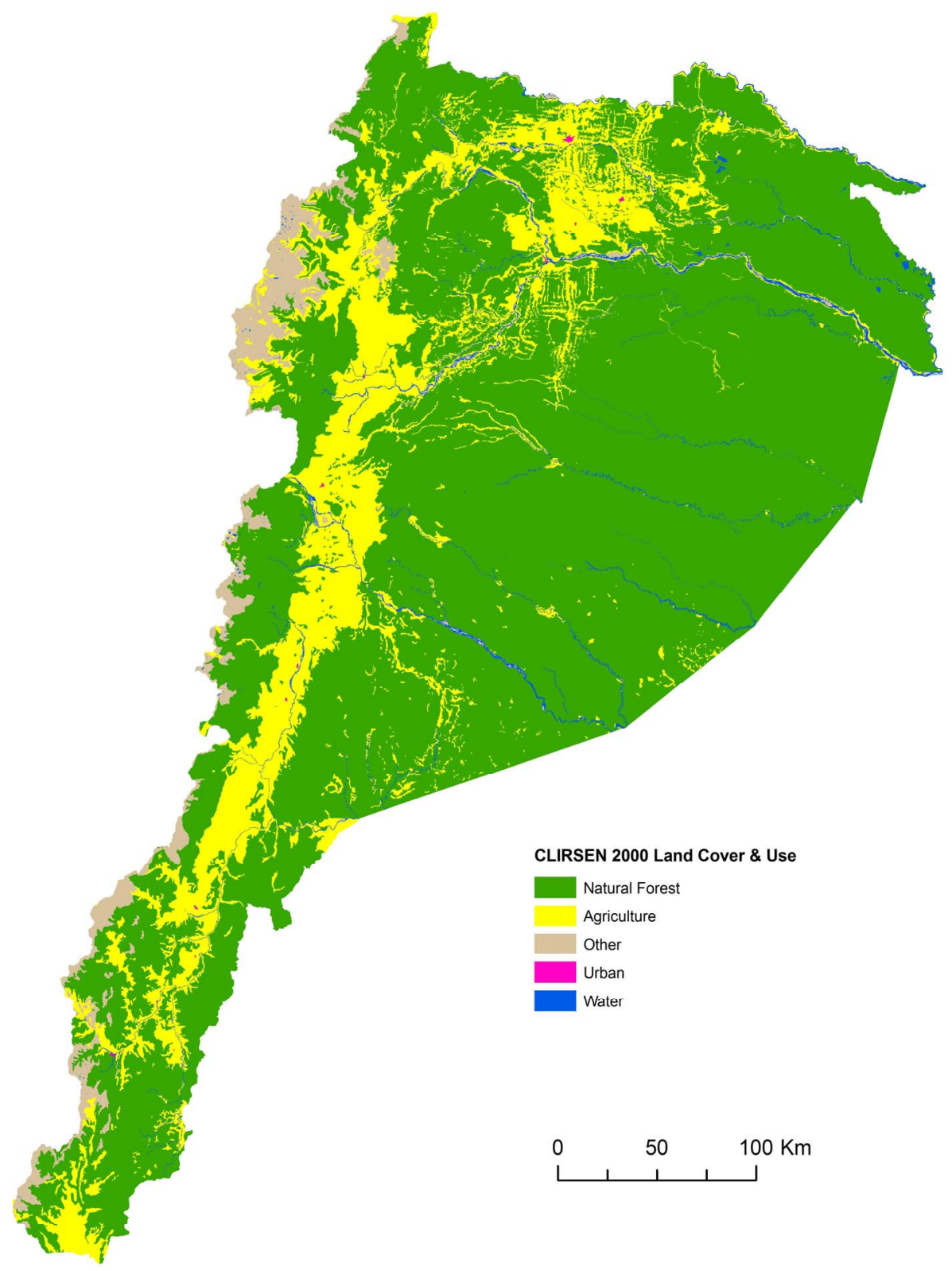

Figure 8. Deforestation in the Oriente, 1965-2000.

\section{Conclusions}

Colonization in Ecuador has occurred wherever roads were built and land was available. Before 1971, four highways extended into the Oriente: Quito-Baeza; AmbatoPuyo-Tena; Cuenca-Limón-Méndez; and Loja-Zamora. Initially, most of the migrants (numbering around 30,000) moved from the southern Andes into adjacent lowland forests, where transportation infrastructure was better; only 10,000 settled in Napo Province (later subdivided into three provinces). But such trends changed after 1972, when the highway from Quito to Lago Agrio was completed. Between 1974 and 1976, Napo's population rose from 62,000 to 86,000 ; by 1982 , it had increased again to
115,000; and in 1992, it reached around 200,000 [64,65]. Since then, population in the area has remained roughly stable despite an elevated rate of natural increase- - suggesting that 120,000 former residents have moved away during the past 20 years.

Between 1964 and 1994, IERAC gave almost 5 million hectares to landless farmers and homesteaders throughout Ecuador; two-thirds of this land was located in the Oriente [47]. In 1994, with no additional vacant lands remaining, the "frontier" was officially closed and IERAC was replaced by a conventional development agency, the Instituto Nacional de Desarrollo Agrario (INDA, the National Institute for Agricultural Development).

What did government officials know about the impact 
of colonization and when did they know it? The evidence is clear. Beginning in 1963, various agencies collected soil samples, hydrological data and other information to determine where settlement should occur $[20,34,66]$. This information was largely ignored in subsequent colonization schemes: "In 1987, [the Ministry of Agriculture and Livestock] completed an evaluation of 5.30 million hectares in northeastern Ecuador. The conclusion was reached that only 17 percent of the region ( 0.90 million hectares) was suitable for crop production and that forests should be maintained on the remaining 83 percent. When the evaluation was carried out, 1.10 million hectares had already been colonized [67]." As we have seen, most of this land became pasture. Between 1972 and 1989, as crop lands in the Oriente grew from 30,000 hectares to 135,000 hectares, pasture lands increased from 384,000 hectares to 880,000 hectares.

Similar events took place in other parts of Ecuador. Along the Pacific Coast, for example, another half-million hectares of intact forest were cut down. Rudel and Horowitz note an "underlying similarity" among major colonization zones: "Timber companies played a significant role in clearing land along Ecuador's northern coast, but smallholders working in corridors along highways have cleared the most land. Oil companies triggered deforestation in the northern Oriente when they constructed roads... but colonists working small tracts of land along the roads have cleared the most land.... Smallholders have cleared almost all of the land in the southern Oriente [68]." In all three regions, they continue, "Smallholders predominate, and an intense competition for land between colonists and indigenous peoples characterizes local politics."

Did colonization address Ecuador's need for food? Early research suggests that it did not. According to the Ministry of Agriculture and Livestock, production of highland crops such as wheat, potatoes and corn in Ecuador declined by more than $70 \%$ during the "land rush" years of 1972-1982. Meanwhile, pasture lands increased twenty-fold, displacing thousands of rural families [69]. Between 1975 and 1980, net rural employment declined by 125,000 workers $(10 \%$ of the agricultural work force)—creating more landless peasants who migrated into the forest. Ultimately, as most specialists recognize, the government's management of petroleum revenues led to other problems: massive public debt (borrowed against future oil production), devaluation, and political instability. After completing a large-scale survey of living conditions in Ecuador, the World Bank concluded in 1991 that "close to four million Ecuadorans, about 35\% of the population live in poverty [70]." Another $17 \%$ were vulnerable to poverty. "One and a half million Ecuadorans live in extreme poverty and cannot meet their nutritional requirements even if they spend everything they have on food [71].” In the Oriente, two-thirds of all rural families remained below the poverty line [72].

What guidance does this analysis provide for conservation and hydrocarbon development in the Western Amazon? Previous researchers have correctly emphasized the role of small-scale settlers and road construction in bringing about widespread deforestation in Ecuador, Peru and elsewhere. Nonetheless, they have neglected to consider a major intervening variable: conflicting priorities within government policy-making. At least in Ecuador, colonization may have been spontaneous and largely undirected, but it was completely intentional. Where deliberate safeguards were put in place to protect the forest and indigenous land rights, as in Villano, relatively little disturbance occurred. Bass et al. offer another example: Block 16, which lies within Huaorani Traditional Territory and the Yasuní National Park [4]. But the fact that safeguards have not become ubiquitous - indeed, that they remain the exception rather than the rule-suggests that policy-makers have not resolved long-standing and widely divergent views of economic development. This does not bode well for preservation of the Oriente.

\section{REFERENCES}

[1] M. Finer, D. N. Jenkins, S. L. Pimm, B. Keane and C. Ross, "Oil and Gas Projects in the Western Amazon: Threats to Wilderness, Biodiversity, and Indigenous Peoples,” PLoS ONE, Vol. 3, No. 8, 2008, Article ID: e22932. doi:10.1371/journal.pone.0002932

[2] Wildlife Conservation Society, "The Global Conservation Program. Achievements and Lessons Learned from 10 Years of Support for Threats-Based Conservation at a Landscape and Seascape Scale,” 2008. http://pdf.usaid.gov/pdf_docs/pdacp728.pdf

[3] E. Suárez, M. Morales, R. Cueva, V. U. Bucheli, G. Zapata-Ríos, E. Toral, J. Torres, W. Prado and J. V. Olalla, "Oil Industry, Wild Meat Trade and Roads: Indirect Effects of Oil Extraction Activities in a Protected Area in North-Eastern Ecuador,” Animal Conservation, Vol. 12, No. 4, 2009, pp. 364-373. doi:10.1111/j.1469-1795.2009.00262.x

[4] M. S. Bass, M. Finer, C. N. Jenkins, H, Kreft, D. F. Cisneros-Heredia, S. F. McCraken, et al., "Global Conservation Significance of Ecuador's Yasuní National Park,” PLoS ONE, Vol. 5, No. 1. p. e8767.

[5] Sven Wunder, "Oil Wealth and the Fate of the Forest," Routledge, London, 2003.

[6] B. T. Orellana, "Avance de la Deforestación de los Bosques Amazónicos del Ecuador,” Centro de Levantamientos Integrados de Recursos Naturales por Sensores Remotos (CLIRSEN), Quito, 2007.

[7] Animaría Varea, "Marea Negra en la Amazonía,” AbyaYala, Quito, 1995.

[8] J. Kimerling, “Amazon Crude,” Natural Resources De- 
fense Council, New York, 1991.

[9] J. Kimerling, "Indigenous Peoples and the Oil Frontier in Amazonia: The Case of Ecuador, Chevron Texaco and Aguinda v. Texaco," Indigenous Law and Politics, Vol. 38, No. 3, 2006, pp. 413-664.

[10] J. Kimerling, “Transnational Operations, Bi-National Injustice: ChevronTexaco and Indigenous Huaorani and Kichwa in the Amazon Rainforest in Ecuador,” American Indian Law Review, Vol. 31, No. 2, 1997, pp. 445-508. doi:10.2307/20070795

[11] S. Sawyer, "Crude Chronicles. Indigenous Politics, Multinational Oil, and Neoliberalism in Ecuador,” Duke University Press, Durham, 2004.

[12] S. Sawyer, "Suing ChevronTexaco,” In: C. de la Torre and S. Striffler, Eds., The Ecuador Reader, Duke University Press, Durham, 2004, pp. 321-328.

[13] D. Schodt, “Ecuador: An Andean Enigma," Westview Press, Boulder, 1987.

[14] World Bank, “World Development Indicators,” 2010. http://data.worldbank.org/data-catalog/world-developmentindicators

[15] G. Philip, “Oil and Politics in Latin America,” Cambridge University Press, Cambridge, 1982. doi:10.1017/CBO9780511528149

[16] M. Whitaker and D. Green, "Development Policy and Agriculture,” In: M. Whitaker and D. Colyer, Eds., Agriculture and Economic Survival: The Role of Agriculture in Ecuador's Development, Westview Press, Boulder, 1990, p. 26.

[17] D. Southgate and M. Whitaker, "Economic Progress and the Environment: One Developing Country's Policy Crisis,” Oxford University Press, New York, 1994.

[18] S. Wunder, "Oil Wealth and the Fate of the Forest," Routledge, London, 2003.

[19] H. Ramos and L. Robison, "Credit and Credit Policies," In: M. Whitaker and D. Colyer, Eds., Agriculture and Economic Survival: The Role of Agriculture in Ecuador's Development, Westview Press, Boulder, 1990, pp. 225245.

[20] World Bank, "Ecuador. Development Problems and Prospects,” World Bank, Washington DC, 1979.

[21] R. Vos, "Petróleo, Estado y Cambio Agrario. Ecuador 1972-1984,” In: P. Gonard, J. León and P. Sylva, Eds., Transformaciones Agrarias en el Ecuador, Centro de Investigaciones Geográficas, Quito, 1988, pp. 21-23.

[22] D. Southgate and M. Whitaker, "Economic Progress and the Environment: One Developing Country’s Policy Crisis,” Oxford University Press, New York, 1994.

[23] C. Larrea, "The Mirage of Development: Oil, Employment, and Poverty in Ecuador,” Ph.D. Thesis, York University, York, 1992.

[24] T. Rudel and B. Horowitz, "Tropical Deforestation. Small Farmers and Land Clearing in the Ecuadorian Amazon,” Columbia University Press, New York, 1993.

[25] D. Southgate, "Policies Contributing to Agricultural Colonization,” In: N. Sharma, Ed., Managing the World's Tropical Forests: Looking for Balance between Conser- vation and Development, Kendall/Hunt Publishing Company, Dubuque, 1992, p. 227.

[26] M. Whitaker, “The Human Capital and Science Base,” In: M. Whitaker and D. Colyer, Eds., Agriculture and Economic Survival: The Role of Agriculture in Ecuador's Development, Westview Press, Boulder, 1990, pp. 301326.

[27] J. L. Gallup, "Geography and Socioeconomic Development (Background Paper),” Andean Competitiveness Project, Harvard University, Cambridge, 2000. http://www.cid.harvard.edu/archive/andes/index.html

[28] F. Pichón, "Sustainable and Inclusive Rural Development,” In: V. Fretes-Cibils, M. Giugale and E. Somensatto, Eds., Revisiting Ecuador's Economic and Social Agenda in an Evolving Landscape, World Bank, Washington DC, 2008, p. 278.

[29] M. Whitaker and J. Alzamora, "Production Agriculture: Nature and Characteristics," In: M. Whitaker and D. Colyer, Eds., Agriculture and Economic Survival: The Role of Agriculture in Ecuador's Development, Westview Press Boulder, 1990, pp. 131-159.

[30] M. Redclift, “Agrarian Reform and Peasant Organization on the Ecuadorian Coast,” Athlone Press, London, 1978.

[31] J. Zevallos, "Oil, Power and Rural Change in Ecuador: 1972-1979,” Ph.D. Thesis, University of Wisconsin, Madison, 1985.

[32] O. Barsky, "Iniciativa Terrateniente en las Transformaciones de la Sierra Ecuatoriana: 1959-1964,” Pontífica Universidad Católica Quito, Quito, 1978.

[33] M. Redclift, "Agrarian Reform and Peasant Organisation on the Ecuadorian Coast,” Athlone Press, London, 1978.

[34] Junta Nacional de Planificación y Coordinación Económica (JNPC), "El Aprovechamiento de la Tierra y el Mar, Tomo II, Reforma a la Estructura de Tenencia de la Tierra y Expansión de la Frontera Agrícola, Capitulo II, Colonización,” JNPC, Quito, 1963.

[35] R. J. Bromley, "The Colonization of Humid Tropical Areas of Ecuador," Singapore Journal of Tropical Geography, Vol. 2, No. 1, 1981, pp. 15-26. doi:10.1111/j.1467-9493.1981.tb00114.x

[36] J. Uquillas, "Indian Land Rights and Natural Resource Management in the Ecuadorian Amazon,” In: T. Macdonald Jr., Ed., Native Peoples and Economic Development. Six Case Studies from Latin America, Cultural Survival, Inc., Cambridge, 1985, pp. 87-103.

[37] L. A, Brown, R. Sierra, D. Southgate and L. Labao, "Complimentary Perspectives as a Means of Understanding Regional Change: Frontier Settlement in the Ecuador Amazon," Environment and Planning A, Vol. 24, No. 7, 1992, pp. 939-961. doi:10.1068/a240939

[38] T. Rudel and B. Horowitz, "Tropical Deforestation. Small Farmers and Land Clearing in the Ecuadorian Amazon,” Columbia University Press, New York, 1993.

[39] J. D. Martz, "Politics and Petroleum in Ecuador," Transaction Books, New Brunswick, 1987.

[40] B. Muratorio, "The Life and Times of Grandfather Alonso,” Rutgers University Press, New Brunswick, 1991. 
[41] Ministerio de Recursos Naturales y Energéticos, “Contrato Celebrado entre el Gobierno del Ecuador (Ministerio de Recursos Naturales y Energéticos) a Favor de las Compañías,” Ecuadorean Gulf Oil Company’ y Texaco Petroleum Company, Quito, 1973.

[42] J. Zevallos, "Oil, Power and Rural Change in Ecuador: 1972-1979,” Ph.D. Thesis, University of Wisconsin, Madison, 1985.

[43] M. Redclift, “Agrarian Reform and Peasant Organisation on the Ecuadorian Coast,” Athlone Press, London, 1978.

[44] J. Zevallos, "Oil, Power and Rural Change in Ecuador: 1972-1979,” Ph.D. Thesis, University of Wisconsin, Madison, 1985.

[45] C. Luzuriaga and C. Zuvekas Jr., "Income Distribution and Poverty in Rural Ecuador, 1950-1979,” Arizona State University Tempe, Arizona, 1983.

[46] H. Barral, "La Región Amazónica Ecuatoriana,” Centro Ecuatoriano de Investigación Geográfica, Quito, 1983.

[47] L. Ruíz, "Amazonía ecuatoriana. Escenario y actores del 2000," EcoCiencia-Comité Ecuatoriano de la UICN (International Union for the Conservation of Nature), Quito, 2000.

[48] J. Uquillas, "Colonization and Spontaneous Settlement in the Ecuadorian Amazon,” In: M. Schmink and C. H. Wood, Eds., Frontier Expansion in Amazonia, 1984, pp. 276-277.

[49] M. Hiraoka and S. Yamamoto, "Agricultural Development in the Upper Amazon of Ecuador," Geographical Review, Vol. 70, No. 4, 1980, p. 429. doi:10.2307/214077

[50] M. Hiraoka and S. Yamamoto, "Agricultural Development in the Upper Amazon of Ecuador," Geographical Review, Vol. 70, No. 4, 1980, p. 433. doi:10.2307/214077

[51] Instituto Ecuatoriano Forestal y de Areas Naturales y Vida Silvestre (INEFAN), "Documentación Sobre la Problemática de los Colonos en la Reserve de Producción Faunística Cuyabeno,” INEFAN, Quito, 1993.

[52] P. E. Little, “Amazonia. Territorial Struggles on Perennial Frontiers,” Johns Hopkins Press, Baltimore, 1991.

[53] E. E. Hegen, "Highways into the Upper Amazon,” University of Florida Press, Gainesville, 1966.

[54] B. Muratorio, "The Life and Times of Grandfather Alonso,” Rutgers University Press, New Brunswick, 1991.

[55] T. Macdonald Jr., "Indigenous Responses to an Expanding Frontier: Jungle Quichua Economic Conversion to Cattle Ranching,” In: N. Whitten Jr., Ed., Cultural Transformations and Ethnicity in Modern Ecuador, University of Illinois Press, Urbana, 1981, pp. 360-361.

[56] N. E. Whitten Jr., “Sacha Runa," University of Illinois Press, Urbana, 1976.

[57] G. Fontaine, “Análisis y Evaluación de la Gestión de los
Conflictos en el Bloque 10 (Ecuador),” Facultad Latinoamericana de Ciencias Sociales (FLACSO), Quito, 2004.

[58] Robin Draper and Christopher Slack, "Narrow Rain Forest ROW Forces Innovation for Ecuadorian Flowline Installation,” Oil \& Gas Journal, Vol. 98, No. 25, 2000. http://www.ogj.com/index/article-display/75621/articles/o il-gas-journal/volume-98/issue-25/transportation/narrow-r ain-forest-row-forces-innovation-for-ecuadorian-flowlineinstallation.html

[59] E. Salazar, "The Federación Shuar and the Colonization Frontier,” In: N. Whitten Jr., Ed., Cultural Transformations and Ethnicity in Modern Ecuador, University of Illinois Press, Urbana, 1981, p. 605.

[60] M. Harner, "The Jívaro. People of the Sacred Waterfalls," Doubleday, Garden City, 1972.

[61] A.-C. Taylor, "God-Wealth: The Achuar and the Missions,” In: N. Whitten Jr., Ed., Cultural Transformations and Ethnicity in Modern Ecuador, University of Illinois Press, Urbana, 1981, p. 651.

[62] T. Rudel and B. Horowitz, "Tropical Deforestation. Small Farmers and Land Clearing in the Ecuadorian Amazon," Columbia University Press, New York, 1993, p. 76.

[63] J. D. Martz, "Politics and Petroleum in Ecuador," Transaction Books, New Brunswick, 1987.

[64] J. Hicks, “Ecuador's Amazon Region,” World Bank, Washington DC, 1990.

[65] Instituto Nacional de Estadística y Censos (INEC), “Censo de Población y Vivienda,” INEC, Quito, 1990.

[66] Instituto Ecuatoriano de Reforma Agraria y Colonización, "La Regionalización Para la Reforma Agraria,” IERAC, Quito, 1976.

[67] D. Southgate and M. Whitaker, "Economic Progress and the Environment: One Developing Country’s Policy Crisis,” Oxford University Press, New York, 1994.

[68] T. Rudel and B. Horowitz, "Tropical Deforestation. Small Farmers and Land Clearing in the Ecuadorian Amazon," Columbia University Press, New York, 1993, pp. 44-46.

[69] R. Vos, "Petróleo, Estado y Cambio Agrario. Ecuador 1972-1984,” In: P. Gonard, J. León and P. Sylva, Eds., Transformaciones Agrarias en el Ecuador, Centro de Investigaciones Geográficas, Quito, 1988, pp. 22-35.

[70] World Bank, "Ecuador. Public Sector Reforms for Growth in the Era of Declining Oil Output,” International Bank for Reconstruction and Development, Washington DC, 1991.

[71] World Bank, "Ecuador Poverty Report," World Bank, Washington DC, 1996.

[72] World Bank, "Ecuador Poverty Report,” World Bank, Washington DC, 1996. 